\title{
ビフィズス菌を配合した機能性食品への 腸溶性シームレスカプセルの利用
}

\author{
河野麻実子 $^{1)}$, 田中 (東) 幸雅 ${ }^{1)}$, 釜口 良誠 ${ }^{2)}$ ，田川 大輔 $^{2}$
}

要約：少子高齢化先進国の我が国において, 健康に年 齢を重ねることは大きな課題となっており，未病段階 でのケアがますます重要となっている，加齢に伴い， 消化管, 循環器, 関節, 脳機能などに様々な不調がみら れるようになるが, なかでも, 消化管機能や筋力の低 下により，高齢者では便秘を発症する人の割合が増え ることがわかっている. また，加齢に伴い，腸内有用 菌であるビフィズス菌が減少するなど, 腸内環境が変 化することも報告されている．シームレスカプセルは， 医薬品や食品で，一般的に広く用いられる「硬カプセル (ハードカプセル)」や「軟カプセル (ソフトカプセル)」 とは異なり, 継ぎ目が無く直径 $0.5 \sim 8 \mathrm{~mm}$ のほぼ真球 の形状をしている。 このシームレスカプセルは, 界面 張力を利用した「液中滴下法」で調製され, 皮膜に耐酸 性, 耐熱性, 腸溶性等の性質を付与することが可能で ある。本技術を利用し，皮膜に耐酸性の性質を持たせ， 腸溶性の機能を付与することで, 胃酸に弱いビフィズ 久菌を，生きたまま腸へ届けることが可能となる．耐 酸性かつ腸溶性シームレスカプセル化ビフィズス生菌 を in vitro 試験で $\mathrm{pH} 1.2$ 模擬胃液中に 2 時間浸漬した後 のビフィズス菌の生存率は, $90 \%$ 以上（非カプセル化 ビフィズス菌の生存率は， $0.0001 \%$ 未満) であることが 示されている. 実際に, この腸溶性シームレスカプセ ル化ビフィズス生菌を摂取することによって, 高齢者 の便秘や QOLが改善することが明らかとなっており， また，血液透析患者においては，ビフィズス生菌の摂 取による腸内環境改善に伴い, 血液中のリン值が低下 することも報告されている。このシームレスカプセル を用いる一種のドラッグデリバリーシステム技術が, 日本の高齢化社会における革新的イノベーションとし て，QOL改善に貢献できるように，検討を続けている.

\section{1.はじめに}

我が国の平均寿命は年々増加しており, 厚生労働省 の平成 26 年簡易生命表によると, いまや男性が 80.50 歳, 女性が 86.83 歳である. 総人口に占める高齢者 （65 歳以上）の割合も年々増加し, 平成 27 (2015) 年 で $26.7 \%$ であり, 平成 72 （2060）年には $39.9 \%$ に達す るといわれ (平成 28 年版内閣府高齢化白書), まさに 超高齢化社会となっている。 一方で, 健康寿命は 2010 年時点で, 男性が 70.42 歳, 女性が 73.62 歳であり, 平 均寿命との差は約 10 年もある（平成 26 年版厚生労働 白書)。この高齢化社会において健康を維持したまま 年齢を重ねることは, 大きな課題の一つであり, 未病 段階でのケアに注目が集まっている.

加齢に伴い, 一般的に様々な不調がみられるように なる，例えば，消化管，関節，脳機能などの不調であ るが，消化管機能や筋力の低下により，高齢者では便 秘を発症する人の割合が増えることがわかっている. また，加齢に伴い，腸内有用菌であるビフィズス菌が 減少するなど, 腸内環境が変化することも知られてお り,これらの変化は高齢者の QOLを低下させるだけ でなく, 昨今の研究では, 様々な疾病との関連が報告 されている(1).

森下仁丹（株）のシームレスカプセル製造技術は, 従来のカプセルに比べて比較的小さな直径 $0.5 \sim 8 \mathrm{~mm}$ のサイズのほぼ球形のカプセルを調製することが可能 であり，皮膜を多層化することにより耐酸性，耐熱性， 腸溶性等の性質を付与することができ，製剤設計の幅 が著しく広い，例えば，耐酸性を有し胃で溶けず腸で 溶解する, 腸溶性を付与したシームレスカプセルは, ビフィズス菌等の機能性成分を胃酸の低 $\mathrm{pH}$ で変質さ

キーワード：シームレスカプセル，腸溶性，ビフィズス菌，Bifidobacterium longum

森下仁丹株式会社 ${ }^{1)}$ 研究開発統括本部 仁丹バイオファーマ研究所, ${ }^{2)}$ カプセル事業本部 カプセル開発部

( 5573-0128 大阪府枚方市津田山手二丁目 11 番 1 号)

E-mail: $\mathrm{m} \_k o h n o @ j i n t a n . c o . j p \quad$ 原稿受領日：2016 年 8 月 18 日，依頼原稿

Title: Application of enteric seamless capsules containing Bifidobacterium longum to functional foods

Author: Mamiko Kohno, Yukimasa Tanaka-Azuma, Ryosei Kamaguchi, Daisuke Tagawa 
せることなく腸まで送り届ける一種のドラッグデリバ リーシステム（DDS）として利用可能であり，この技 術が日本の高齢化社会において, 高齢者の QOL 改善 に貢献できると期待している，本稿では，高齢者の加 齢に伴う不調, 特に便秘の改善における本技術の応用 について概説する.

\section{2. 腸溶性シームレスカプセルについて}

医薬品や食品で，一般的に広く用いられるカプセル には,「硬カプセル (ハードカプセル)」や「軟カプセ ル (ソフトカプセル)」がある. 硬カプセルは, 医薬品 で多く利用されているもので，ボディとキャップを組 み合わせる形式であり，主に粉末や顆粒をボディに封 入し，キャップをはめ込むようにして製造される。 ま た，軟カプセルは，健康食品で多く利用されており， 親油性の液体や油脂に懸濁した粉末などをフィルム状 のシートで挟み込み，圧着して成型される $(2)$. いず れのカプセルも複数のパーツを組み合わせたあるいは つなぎ合わせた皮膜となっている点に特徴がある.

一方, シームレスカプセルは, 継ぎ目のない真球状 のカプセルであり, 継ぎ目から外部の液体などが侵入 することがないため，内容物を外部環境から保護する 用途に適している．前述のカプセルとは製法が異なり， 同心多重ノズルを用いた「液中滴下法」で調製される。 「液中滴下法」とは, 界面張力を利用した製造方法であ る，流下する溶液（キャリアー液という）に，同心の 二重のノズルを用いて皮膜物質と内容物を同時に吐出 し，キャリアー液中での界面張力により皮膜物質が内 容物を包み込んで, 真球状の液滴を形成した後, 固化 により形成する方法である。皮膜物質としては，温度 の違いにより溶液状態 (ゾル) から固体状態 (ゲル化) に変化する物質が使用される，例えば，食品の場合， ゼラチン，寒天等の水溶性高分子である。この皮膜物 質を工夫することで, 耐酸性, 耐凍性, 耐熱性などの 対環境性能の向上や, 温度や $\mathrm{pH}$ 応答性などによるカ プセルの崩壊条件の制御性を付与した，例えば耐酸性 で胃では解けず腸で溶解する機能をもったシームレス カプセルを調製することが可能となる。ささらに，ノズ ルを多重にすることで，三層，四層のカプセルを調製 することが可能であり, 各層は界面が形成される物質 の組み合わせであればよいので，内容物としては，親 油性物質, 親水性物質のいずれも包み込むことができ る. シームレスカプセルのサイズは, 粒径 $0.5 \sim 8 \mathrm{~mm}$ 程度であり，顆粒のような小さなカプセルも製造でき ることが特長のひとつである，食品の場合，このよう な特長を組み合わせることで, 内容物の特性, 利用率,

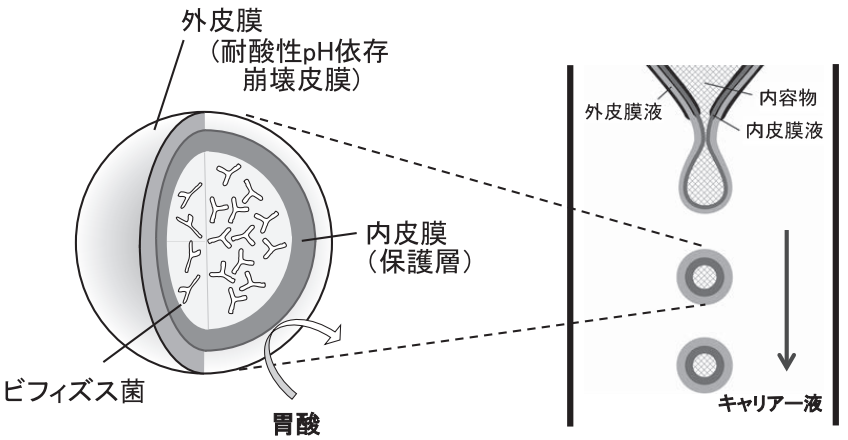

図 1 液中滴下法による三層構造の腸溶性シームレスカプセル製造 法模式図

飲みやすさを考慮したカプセル（キャリアー）とする ことができる。 なかでも，腸溶性シームレスカプセル は, 皮膜に耐酸性 $\mathrm{pH}$ 依存崩壊能を付与しており, 作 用部位が下部消化管で，胃酸での分解や変性が問題に なる機能性物質を保護し，その効果を発揮させるのに 有用なカプセルである。 その代表例が，ビフィズス菌 を包含した腸溶性シームレスカプセルである（図 1).

ビフィズス菌は，腸内有用菌であり，プロバイオ ティクス（宿主の腸内細菌叢のバランスを改善するこ とにより，宿主に有益な作用をもたらす生きた微生 物 (3)）として, ヨーグルトやサプリメントに利用され ているが，酸に弱いことが知られている(4)。つまり， ビフィズス菌を経口で摂取した場合, 胃において $\mathrm{pH}$ の低い胃酸により生存率が低下し, 作用部位である腸 まで生きたまま届けることが困難であると考えられる. そこで，腸溶性シームレスカプセルを一種の DDS と して利用することで生きたビフィズス菌の腸への到達 率の向上が期待された。このシームレスカプセルは, 三重ノズルを使用して調製される三層構造となってい る，最外層の皮膜には，酸性領域では溶解しないが中 性領域で溶解する物質（ペクチン等）を配合すること で, $\mathrm{pH}$ 応答性によりカプセルが胃で溶けず腸で溶け るように設計している. カプセルの中間層の内皮膜に は硬化油脂を使用し，胃酸などの透過に対するバリ アー機能の向上を図っている，最も内側の層に内容物 （ビフィズス菌凍結乾燥菌末）を封入し, 前述の最外層 および中間層の二層の皮膜による一種の DDS を実現 している. ビフィズス菌乾燥菌末のような粉末を内容 物にする場合は，油脂等に懸濁することで，液中滴下 法により連続してシームレスカプセル内に封入するこ とが可能となる.

このように作製された腸溶性シームレスカプセル （直径 $2.5 \mathrm{~mm}$ ）は, 人工胃液中で高い生存率を示す. 日本薬局方溶出試験法に用いられる溶出試験装置を使 


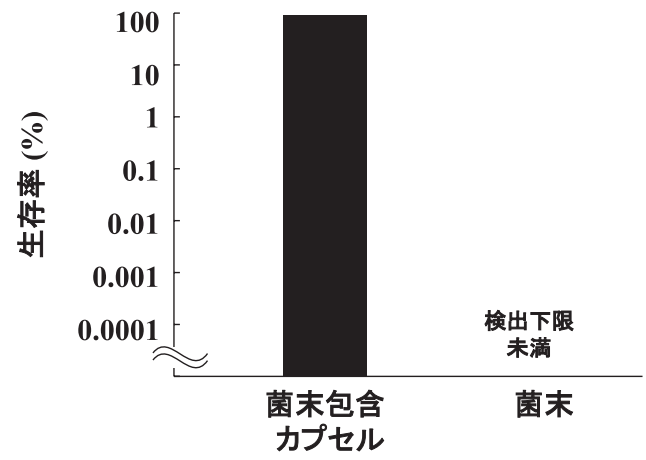

図 2 ビフィズス菌 (Bifidobacterium longum) の菌末とシーム レスカプセルに配合されたビフィズス菌の人工胃液 $(\mathrm{pH} 1.2$ 溶液 $)$ 中での生存率（文献 5,6 のデータよりグラフ作成）

$37^{\circ} \mathrm{C}, 2$ 時間溶出試験装置で擋拌後の生存率を示す。

用し, pH 1.2 の人工胃液（日本薬局方溶出試験第 1 液 を使用) 中に, ビフィズス菌 (Bifidobacterium longum) の凍結乾燥菌末を包含したカプセルを加え，2 時間擋 拌を行った後の生存率を検証すると，90\%以上という 高い生存率を示すことが明らかとなっている（図 2). 一方，カプセル化していない凍結乾燥菌末のみで検証 すると，その生存率は検出限界未満 (0.0001\%未満)で あり，腸溶性シームレスカプセルにより高い耐酸性を 付与できることが示されている $(5,6)$. 腸溶性シーム レスカプセルは, $\mathrm{pH}$ の低い胃を通過した後, 腸に届く ころ, $\mathrm{pH}$ が中性付近に変化することで, $\mathrm{pH}$ 応答性を 有する外皮膜が溶解する。 その後, 中間層の硬化油脂 から成る内皮膜が, 胆汁酸とリパーゼによる分解を受 け，さらに腸管運動による物理的刺激も加わり崩壊し， ビフィズス菌が腸内で放出され，作用部位である腸ま で生きたまま届くのである(7).

実際にヒトでもこのカプセル化ビフィズス菌の摂取 により排便回数の増加などの効果が認められている. 非腸溶性の硬カプセルあるいは腸溶性シームレスカプ セルに包含された同菌数の生きたビフィズス菌 (Bifidobacterium longum 12.5 億 $\mathrm{CFU}$ ) を, 大学生を対 象として， 2 週間摂取させた試験では，腸溶性シーム レスカプセル化ビフィズス菌摂取により，1 週間毎の 排便日数が, 摂取 1 週目から有意に増加し, 摂取 2 週 目 $(P<0.05)$, 摂取中止後の 2 週間においても有意な 増加を維持した。ささらに，摂取 2 週目には，非腸溶性 硬カプセル化ビフィズス菌摂取群との比較においても, 有意に多い排便日数を示した $(P<0.05)$ ことが報告さ れている(図 3) (8).

また，ビフィズス菌（Bifidobacterium longum）の生 菌と死菌を摂取した際の比較検証も，健常成人 10 名 （平均年齢 56.8 歳）を対象として，実施されている.

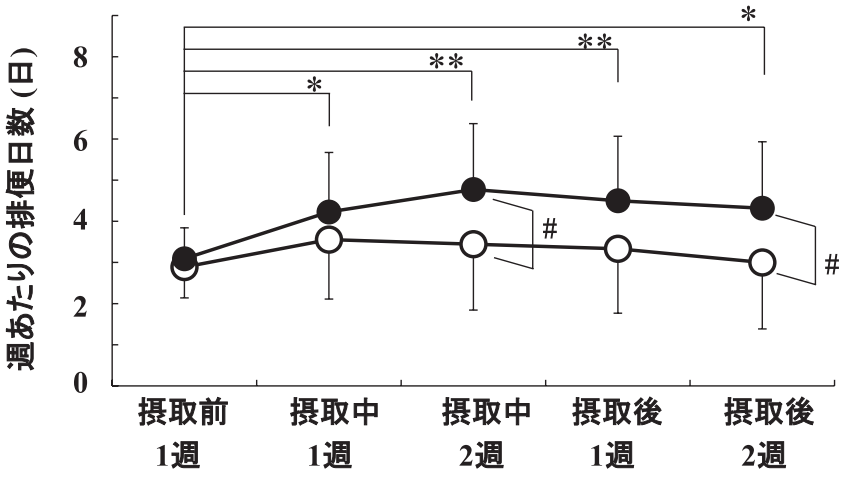

図 3 腸溶性シームレスカプセルとハードカプセルの比較検討（8） データは, 平均值士標準偏差で表した．腸溶性シームレスカプセル配合 ビフィズス菌摂取群 $(\boldsymbol{O}, \mathrm{n}=22)$ ，非腸溶性硬力プセル配合ビフィズス 菌摂取群 $(\bigcirc, n=9) .{ }^{*} P<0.05$, 腸溶性シームレスカプセル群と非腸 溶性硬力プセル群との比較。 ${ }^{*} P<0.05, * * P<0.01$, 腸溶性シームレス カプセル群の摂取前の排便日数との比較.

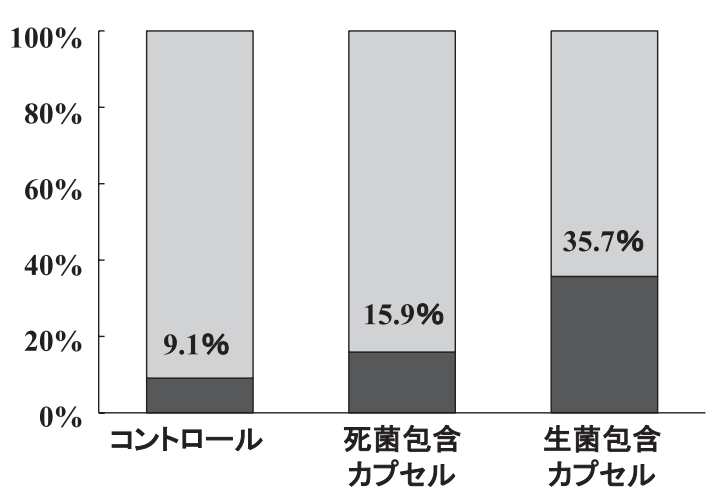

図 4 腸溶性シームレスカプセルに配合されたビフィズス菌の摂取 効果 (9)

腸溶性シームレスカプセル配合ビフィズス菌を2 週間摂取した後のビ フィズス菌占有率を示す。

腸溶性シームレスカプセル化生菌（Bifidobacterium longum 10 億 CFU）を 2 週間摂取したところ，摂取前 に比べ，糞便中総菌数に占めるビフィズス菌の割合 (占有率) が $9.1 \%$ から $35.7 \%$ 一増加するが，同菌数の 死菌を包んだ腸溶性シームレスカプセルを摂取した場 合，摂取後のビフィズス菌占有率は $15.9 \%$ であり，生 菌を包んだ腸溶性シームレスカプセルの方が，効果的 に腸内ビフィズス菌を増加させることが示されている (図 4) (9).

これらはいずれも, 腸溶性シームレスカプセルが一 種の DDS として機能を発揮し，ビフィズス菌を生き たまま腸まで届けることで, 効果的な腸内環境, 便通 改善をもたらすことを示す結果と考えられる.

\section{3. 高齢者の腸内環境と腸溶性シームレスカプ セル包含ビフィズス菌摄取の効果}

前述のとおり, ビフィズス菌は腸内有用菌であるが, 
加齢とともに腸内に打ける菌数は減少することが知ら れている．また，加齢に伴い排便障害，便秘が増える ことも知られている. 高齢になると, 食事量や運動量 の低下や，筋力など身体機能の低下，感受性機能の低 下が要因となるようである，実際，我々が実施したア ンケート調査でも, 高齢者（60歳以上）の約半数はお なかの調子に悩みを有しており，その悩みは加龄とと もに増加することがわかっている．特に男性は顕著で ある (10)。

平均年齢 64.8 歳の高齢者を対象に, 腸溶性シームレ スカプセル化ビフィズス菌 (Bifidobacterium longum 50 億 CFU）の効果を検証した試験がある。便秘傾向 がある高齢者 28 名に, 腸溶性シームレスカプセルあ るいは，ビフィズス菌を含まないプラセボカプセルを 2 週間摂取させる二重盲検クロスオーバー試験を行っ た。 その結果, プラセボカプセル摂取時の排便回数 (2 週間の平均排便回数 $4.1 \pm 0.8$ 回 / 週 $)$ に比べて, 腸溶 性シームレスカプセル化ビフィズス菌摂取時の排便回 数 (2 週間の平均排便回数 $4.6 \pm 1.1$ 回 / 週) が, 有意 に高いことが確認された。また，各カプセル摂取 2 週 間後の腸内におけるビフィズス菌の占有率も, プラセ ボカプセル摂取時に比べて, 腸溶性シームレスカプセ ル摂取時に有意に増加した。このように，腸溶性シー ムレスカプセル化ビフイズス菌が, 高齢者の腸内環境 改善あるいは便通改善に寄与できることが示されてい る(11).

\section{4. 血液透析患者に対する腸溶性シームレスカ プセル包含ビフィズス菌の効果}

腸溶性シームレスカプセル化ビフィズス菌の摂取は, 血液透析患者の便秘改善にも寄与すると報告されてい る. 透析患者は, いまや 30 万人を超え, その平均年齢 は約 68 歳であり, 高齢化社会の問題のひとつである (12). 透析に関する問題もさることながら, 透析を受 ける多くの患者が，水分や食事の制限を受けることか ら便秘になりやすいことも QOL の観点から問題と なっている．このような背景をもつ慢性維持透析患者 (24名) が, ビフィズス菌 (Bifidobacterium longum 20 億 $\mathrm{CFU}$ ）を含む食品を, 2 力月間毎日摂取したところ, 21 名（87.5\%）に便秘の改善と QOL の向上（便秘症状に 伴う QOL を評価する尺度である PAC-QOL，The Patient Assessment of Constipation Quality of Life Questionnaire を用いた評価）が認められた。具体的には，日本語版 便秘評価尺度（CAS：Constipation Assessment Scale） を使用した評価において, 摂取開始直前の CAS 合計平 均点が 9.1 点 (5 点以上が便秘と判断される) であった
ところ, 摂取 1 週目に 6.2 点となり, 続いて, 捸取 2 週目，摂取 3 週目でも有意な低下 $(P<0.01)$ を示した. さらに, 摂取 3 週目以降も摂取終了まで, 5 点未満を 維持した。また，PAC-QOLを使用した評価においても， 摂取後に有意な低值 $(P \leqq 0.0001)$ を示すなど， QOL の改善が認められている(13)。 また, 透析患者が腸溶 性シームレスカプセル化ビフィズス菌を摂取すること による別の作用も明らかとなっている. 維持血液透析 患者 15 名に, ビフィズス菌（Bifidobacterium longum 20 億 CFU）を含む食品を，1 カ月摂取させたところ， 摄取 2 週目 $(P<0.001), 4$ 週目 $(P<0.01)$ に, 血液中 のリン值が有意に低下し, 非摂取の透析患者 16 名と の比較に打いても, 摂取 2 週目 $(P<0.001), 4$ 週目 $(P<0.05)$ に，血液中のリン值が有意に低值であった ことが報告されている（図 5) (14)。この作用は, 腸溶 性シームレスカプセル化ビフィズス菌の摂取により, 腸内環境が改善し, 腎不全状態下で上昇した腸管内 $\mathrm{pH}$ が低下した結果, カルシウムのイオン化率が上昇 し，リン吸着片様の効果を発揮することで吸収される リンが減少し，血中リン濃度が低下することが一因で あることが，動物試験により明らかとされている(15). 透析患者の血中リン值の上昇は, 動脈硬化の要因にな るため,コントロールが重要であり, リン吸着剤など の医薬品や食事療法で対処されるが, 腸溶性シームレ スカプセル化ビフィズス菌の摂取は, 透析患者の便秘 の改善も期待できるため，きわめて有効な方法のひと つと考えられる.

このように，腸溶性シームレスカプセル化ビフィズ ス菌は，高齢化社会における，加齢に伴う便秘だけで なく, 病者の腸内環境改善にも寄与し, QOLの改善に つながることが期待できる.

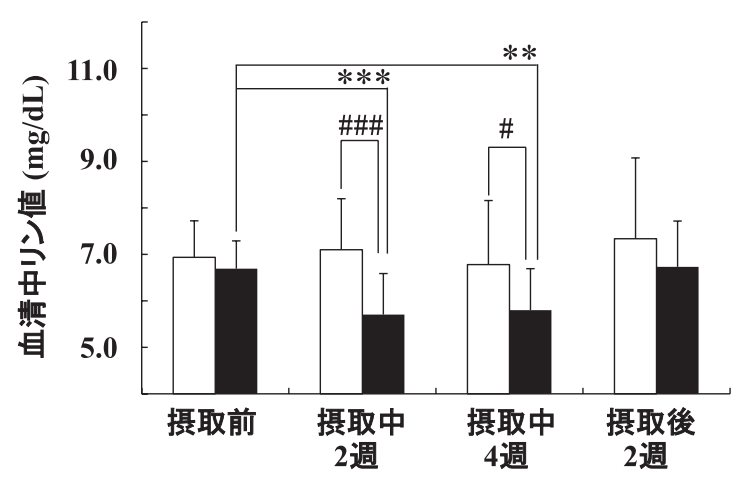

図 5 腸溶性ビフィズス菌カプセル摂取による血液透析患者の血清 リン值の変化（文献 14 のデータよりグラフ作成）

デー夕は, 平均值士標準偏差で表した. 腸溶性シームレスカプセル配合 ビフィズス菌摂取群 $(\boldsymbol{\square}, \mathrm{n}=15)$, 非摂取群 $(\square, n=16)$. \#\# $P<0.001$ 。 ${ }^{\#} P<0.05$, 腸溶性シームレスカプセル配合ビフィズス菌摂取群と非摂取 群との比較. ***P $P<0.001, * * P<0.01$, 腸溶性シームレスカプセル配 合ビフィズス菌摂取群の摂取前との比較. 


\section{5. おわりに}

高齢化社会に扔いて, 未病段階でのケアや QOLの 改善により, 健康寿命を延伸することは大きな課題で ある。本稿では, 森下仁丹（株）のシームレスカプセ ル化技術を利用した一種のドラッグデリバリーシステ ムが, 加龄に伴う不調のうち, 便秘や腸内環境改善に 寄与することを紹介したが，本技術はこれにとどまら ず，多くの機能性成分をより効果的に利用する手段と なり得る．多層のシームレスカプセル化技術が，高齢 化社会において，革新的なイノベーションを起こす技 術のひとつとなり, 健康寿命の延伸, 高齢者の QOL改 善に貢献できるように，今後も検討を重ねて行きたい.

著者の利益相反：河野麻実子, 田中(東) 幸雅, 釜口良誠, 田川大輔（森下仁丹株式会社）。
文献

1) 福田真嗣. 腸内細菌学雑誌. 2015;29:145-155.

2）高橋雅人. DDS 製剤の開発・評価と実用化手法. 技術情報協 会; 2013. p. 106-109.

3) Fuller R. J Appl Bacteriol. 1989;66:365-378

4) 馬田三夫. ビフィズス菌の研究. 日本ビフィズス菌センター; 1994. p. 267-275

5) 河野麻実子. Medical Science Digest. 2016;42:45-48.

6) 河野麻実子. ヨーグルトの事典. 朝倉書店; 2016. p. 374-379.

7) 浅田雅宣. Anti-aging Science. 2010;2:61-66.

8) 浅田雅宣, 他. 第 60 回日本栄養改善学会学術総会講演要旨 集. 2013; 講演番号 3Ep-07.

9) 李雪駝,他. 第 16 回日本食品微生物学会学術総会講演要旨集. 1995; 90 .

10）河野麻実子. 日本補完代替医療学会学術集会抄録集. 2008;117.

11) 河野麻実子. 日本乳酸菌学会誌. 2008;19:114.

12 ) 図説 わが国の慢性透析療法の現況(2014 年 12 月 31 日現在). 日本透析医学会.

13）辻 義弘, 他. 日本透析医学会雑誌. 2015;48:413-422

14) Ogawa T, et al. Clin Kidney J. 2012;5:373-374.

15) Nagano N, et al. Adv Microbiol. 2015;5:531-540. 